\title{
BEING POOR AND BECOMING POOR: \\ Poverty Status and Poverty Transitions \\ in Rural Pakistan
}

\author{
IDSWORKING PAPER 79
}

\section{Bob Baulch and Neil McCulloch*}

\begin{abstract}
SUMMARY
Conventional poverty profiles and poverty status regressions are often criticised by policy makers for telling them a lot about who the poor are, but very little about what to do to combat poverty. Essentially this is because the correlates of poverty status are distinct from the dynamic processes that lead households to fall into or escape from poverty. This paper contrasts the results of conventional poverty status regressions with an alternative approach, the analysis of poverty transitions, using a five year longitudinal household survey from rural Pakistan.
\end{abstract}

The results show that while the incidence of income poverty in the sample villages was high, turnover among the poor was also rapid. In each year of the survey between 21 per cent and 29 per cent of households had incomes below the poverty line, but 46 per cent to 51 per cent of poor households exited poverty from one year to the next. Only 3 per cent of households were poor in all five years of the panel. Furthermore, the correlates of entries and exits from poverty were found to differ in important but unexpected ways from those of poverty status. The dependency ratio and geographic variables were important correlates of poverty status, but neither had much impact on entries into or exits from poverty. Other variables, such as education and livestock ownership, had asymmetric impacts on poverty transitions: increasing exit or reducing entry probabilities without influencing transitions in the opposite direction. Further analysis, however, is necessary to identify the events which preceded households moving into or out of poverty.

The policy implications of these findings, if confirmed elsewhere, indicate that targeting anti-poverty policies using the characteristics of the currently poor is highly problematic. If governments care primarily about reducing the poverty headcount, they should focus their efforts on increasing exits from and decreasing entries into poverty. Focusing anti-poverty efforts on the correlates of poverty status means that it is the symptoms rather than the causes of poverty that are being addressed.

\footnotetext{
" Respectively, Fellow and Research Officer, Institute of Development Studies at the University of Sussex. The authors thank IFPRI for granting them access to the Pakistan panel data set and Richard Adams, John Hoddinott, Stephen Jenkins and participants at seminars at the LSE, IDS and UoS for helping them think through the methodology. Stephen Devereux, Howard White and Adrian Wood made valuable comments on earlier versions of this paper, while Jenny Edwards provided excellent secretarial support. All errors remain the responsibility of the authors and senior authorship is not assigned.
} 


\section{INTRODUCTION}

There is a popular perception that poverty in both developing and industrialised countries is a structural, long-term phenomenon or as St Mark's gospel (Chapter 14, verse 7) puts it, that "the poor you shall ever have with you". Yet evidence from longitudinal household surveys in industrialised countries such as Germany, the UK and the USA indicates that poverty is mostly a temporary phenomenon (Duncan, et al., 1993). Rather than the same people remaining below the poverty line year in and year out, a high percentage of households have been shown to move into poverty due to temporary shocks (such as illness or loss of employment) that are reversed just one or two years later. Similarly, many of the people who escape poverty only succeed in doing so for one or two years before a reversal in their circumstances forces them back below the poverty line. Viewed in this light the "poverty problem" is one involving a large turnover of vulnerable people rather than a hard-core of the chronically poor.

The relatively few longitudinal household studies that exist for South and East Asia seem to confirm this characterisation of poverty as a temporary phenomenon. Work by ICRISAT in eight villages in southern India in the late 1970s and early 1980s found that around a quarter of poor households moved out of poverty from year to year (Walker and Ryan, 1990). Similar results have been observed in four villages in rural Pakistan (Adams and He, 1995), in four provinces in southern China (Ravallion and Jalan, 1996) and using a sub-sample of the All India National Household Sample Survey (Gaiha, 1989). None of these studies, however, investigated which factors were associated with movements into and out of poverty and how they compare with the static correlates of poverty.

The nature of poverty dynamics has immediate relevance for the design of cost-effective poverty reduction strategies. Knowledge of the factors associated with movements in and out of poverty ought to allow anti-poverty policies to be targeted at particular vulnerable groups. If, for example, loss of employment or changes in family status (in particular child-birth, divorce and widowhood) typically precede movements into poverty - as has been found in many industrialised countries - then employment guarantee schemes combined with support for mothers and female headed households have a crucial role to play in anti-poverty initiatives. Furthermore, information concerning the length of time that different categories of households spend in poverty, and the frequency with which spells of poverty recur, is important in determining the nature of such interventions. Numerous short, recurring spells of poverty indicate that priority should be given to measures such as safety nets, credit and insurance schemes designed to support vulnerable households during hard times. In contrast, extended spells of poverty point to policies (such as education, land reform, or improved disability and old age pensions) that improve the assets and entitlements of the poor.

This paper investigates these issues using a unique household panel data study for rural Pakistan between 1986/87 and 1990/91. After describing our methodology and the data set, the paper undertakes a traditional analysis of the correlates of poverty status. It then investigates the extent of movements into and out of poverty amongst the sample households and explores the correlates of such transitions. It finds that the correlates of poverty transitions differ from those of poverty status. The final section draws some tentative policy conclusions from these results and discusses the future directions of our research. 


\section{METHODOLOGY}

This paper's central concern is to explore the contrast between the correlates of poverty status and those of poverty transitions. To do this two conventional modelling approaches, a Logit model of poverty status and a proportional hazards model of poverty transitions, are employed. But before either of these analyses can be undertaken, it is necessary to define poverty and poverty transitions.

Throughout this paper, an income-based definition of poverty is used. This is not to deny the importance of consumption-based or multi-dimensional approaches to the measurement of poverty - indeed, there is now a large literature on the multi-faceted nature of poverty and the importance of integrating "qualitative" and "quantitative" approaches to poverty measurement. However, most poverty analysts would agree that the inability to acquire a certain minimum bundle of goods lies at the core of most concepts of poverty. Furthermore, income- or consumption-based definitions of poverty have the advantage of clearly dividing a population into mutually exclusive categories. Although consumption-based poverty measures are usually more stable than those of income (Lipton and Ravallion, 1995), we have adopted an income-based definition of poverty because this is the variable we are able to track over all five years of the panel. However, the methods used in this paper could be applied to any mutually exclusive indicator of poverty.

Whenever a household's income crosses over the poverty line that household makes a poverty transition. An increase in income that moves a household over the poverty line is defined as an exit or movement out of poverty, while a decrease in income that moves a household's income below the poverty line is defined as an entry or movement into poverty. One difficulty that arises with such a definition of poverty transitions is that if a household's income is close to the poverty line relatively small changes in income may be associated with exits out of and entries into poverty. To avoid this problem, we have adopted a definition of poverty transitions which requires a household to experience both a change in real income of 10 per cent or more and to have crossed the poverty line before it is said to enter or exit poverty. In addition, because the position of the poverty line is itself often debatable, we have repeated our analysis using a wide range of poverty lines.

The correlates of poverty status are usually analysed using either a poverty profile or a poverty status regression. Poverty profiles identify the characteristics of the poor using a tabulation approach and usually do not allow more than one correlate of the poor to vary simultaneously. In contrast, poverty status regressions aim to analyse the correlates of poverty in a multivariate framework. They are usually implemented using a Probit or Logit model in which a dichotomous variable representing whether or not a household is poor is regressed on a set of supposedly exogenous explanatory variables (such as region of residence, household size and composition, asset ownership, etc.). ${ }^{1}$ Typically certain explanatory variables will be identified which are significantly associated with being poor or non-poor. The results of such poverty

Following Ravallion (1996), it is possible to object to this procedure - together with our subsequent use of a proportional hazards model to examine poverty transitions - on the grounds that it 'throws away' data on the level of income. Poverty profiles and poverty status regressions are, however, used so frequently in framing antipoverty policies that we would argue it is vital to understand how the correlates of poverty status and poverty transitions differ. 
status regressions are generally taken to indicate that policy should focus on enhancing the factors associated with not being poor and diminish those associated with being poor.

When framing anti-poverty policies it is, however, important to be very careful in interpreting the results of poverty status regressions. Strictly speaking the explanatory variables included in a poverty regression should be exogenous of a household's poverty status. Yet it is clear that poverty status regressions often identify strong associations between poverty and certain explanatory variables (such as household size or asset ownership) which, at least in the medium to long-term, are as much the consequences as the causes of poverty. Knowledge of such correlates of poverty status can be useful in targeting anti-poverty interventions but typically shed little light on the specific events and processes which "cause" households to become poor. ${ }^{2}$ For example, it is common in poverty status regressions for certain asset variables to be negatively correlated with poverty status. If this is because having more of an asset (e.g., land) enables households to escape poverty then anti-poverty policy might usefully focus upon asset (i.e., land) redistribution. However, if the association arises because rich households tend to buy more of an asset (e.g., jewellery) than poor ones, then there may be no link between the amount of an asset which a household possesses and its chances of escaping from poverty.

It is therefore important to explore the dynamics of poverty in order to understand the correlates and causes of movements into and out of poverty. The most straightforward approach to this is to examine poverty transition matrices. A poverty transition matrix shows the number of households in and out of poverty in a particular period, broken down by their poverty status in a previous period. Thus it is easy to see the number of households who have been poor or non-poor in both periods along with the number who have escaped poverty and those who have entered poverty. This approach has been used in a number of studies in both industrialised and developing countries.

From any poverty transition matrix it is straightforward to calculate simple probabilities of entering and exiting poverty between the two periods. For example the simple probability of exiting poverty is simply the number of households exiting poverty divided by the number of households who were poor in the previous period. To understand the relationship between entry and exit probabilities and the incidence of poverty, it is helpful to consider the simple first-order Markov model in Figure 1:

The use of poverty correlates in targeting also requires caution as some poverty correlates (e.g., education status) suffer from a "fallacy of composition": educating all poor households is unlikely to raise them all out of poverty unless there is an unmet demand for educated labour. 


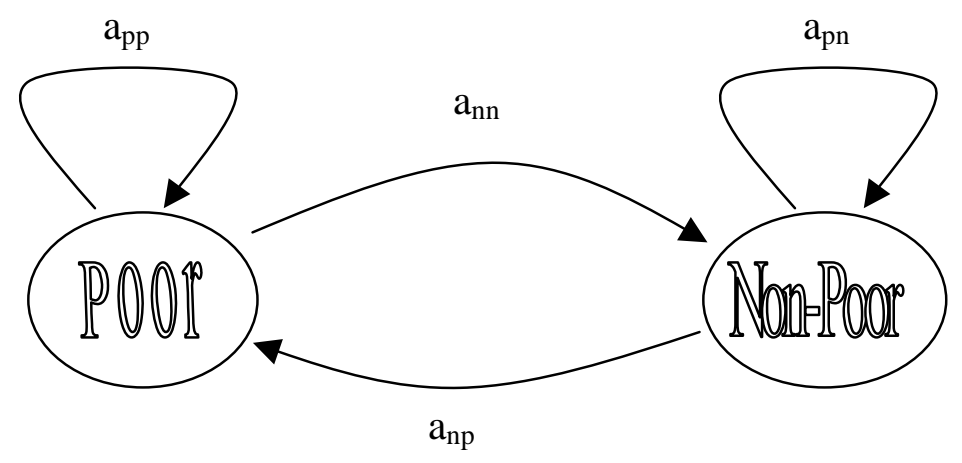

Where $\mathrm{p}$ denotes poor and $\mathrm{n}$ denotes non-poor. Thus

$\mathrm{a}_{\mathrm{pp}}=$ probability of staying poor

$\mathrm{a}_{\mathrm{nn}}=$ probability of staying non-poor

$\mathrm{a}_{\mathrm{pn}}=$ probability of exiting poverty

$\mathrm{a}_{\mathrm{np}}=$ probability of entering poverty

Let $\mathrm{H}$ be the proportion of the population who fall below the poverty line in any period - that is, the poverty headcount. Then in a steady-state (i.e. where the headcount has reached its equilibrium value $\mathrm{H}^{*}$ ) the number of households moving out of poverty must equal the number of households moving into poverty. That is:

$$
\mathrm{H}^{*} \cdot \mathrm{a}_{\mathrm{pn}}=\left(1-\mathrm{H}^{*}\right) \cdot \mathrm{a}_{\mathrm{np}}
$$

Solving this for the steady-state headcount gives:

$$
\mathrm{H}^{*}=\frac{\mathrm{a}_{\mathrm{np}}}{\left(\mathrm{a}_{\mathrm{pn}}+\mathrm{a}_{\mathrm{np}}\right)}=\frac{1}{\left(\left(\frac{\mathrm{a}_{\mathrm{pn}}}{\mathrm{a}_{\mathrm{np}}}\right)+1\right)}
$$

This results makes intuitive sense; the headcount is reduced the larger the ratio of the probability of exiting poverty to the probability of entering poverty. Figure 2 shows the relationship between the steady-state headcount and this ratio. 


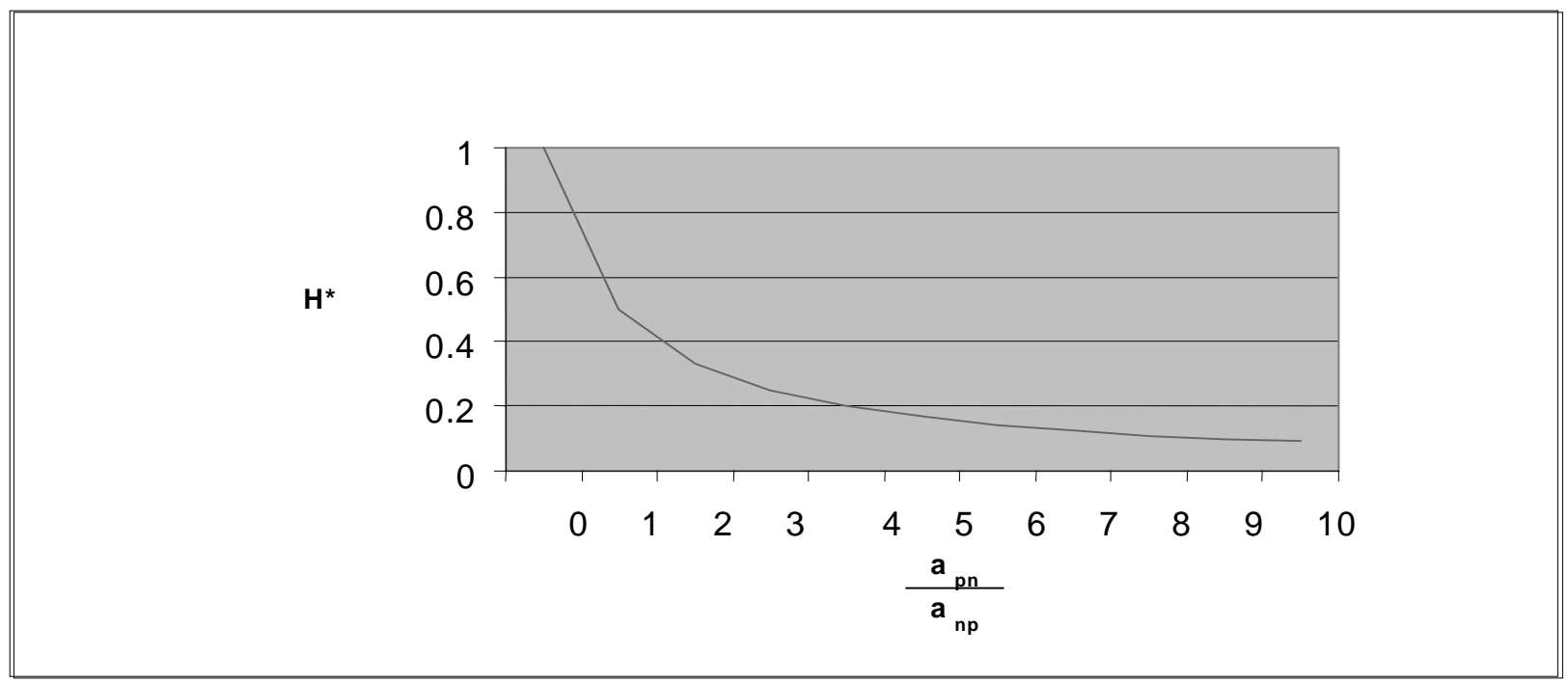

Thus if the ratio of the probability of exiting poverty to the probability of entering poverty is, say, 4 , the long-run poverty headcount will be 20 per cent. This suggests that if interventions can successfully increase the probability of exiting poverty and decrease the probability of moving into poverty then they will be successful in reducing the long-run poverty headcount ${ }^{3}$.

In order to determine which policies are most likely to influence the probabilities of moving into and out of poverty, a method of determining the factors which influence entries into and exits from poverty is needed. However, the probability of exiting or entering poverty may be influenced by the length of time a household has already been poor or non-poor. Consequently, simple entry and exit probabilities cannot be regressed on a set of explanatory variables without introducing biases into the results. Our solution is to model the probability of exiting from a "spell" of poverty - that is, we look at the conditional probability of a household moving out of poverty given that it has not yet exited and we observed the household falling into poverty at an earlier period. This is the approach taken by Bane and Ellwood in their seminal study of poverty spells in the USA (Bane and Ellwood, 1986). Note that the fact that we observed the household falling into poverty is important. Like all panel data sets, our data suffer from left-censoring; a household may enter the panel in poverty, but we do not know when that household became poor. Similarly, a household may start non-poor, but we do not know when they became non-poor. To avoid this problem, we model the probabilities of entry (exit) into poverty (non-poverty) after completed spells of non-poverty (poverty).

3 The equation in the text shows the long-run equilibrium value of the headcount. However, when the probabilities of entry and exit changes there will be a short-run adjustment given by the first order differential equation:

$\frac{d H}{d t}=(1-H) a_{n p}-H \cdot a_{p n}$.

The solution to this equation is: $H=\left(H_{0}-H^{*}\right) e^{-\left(a_{m p}+a_{m i}\right) t}+H^{*}$

where $\mathrm{H}^{*}$ represents the steady-state headcount shown above and $\mathrm{H}_{0}$ is the headcount in the first period. Thus the solution consists of an exponential adjustment towards the steady-state, the speed of which depends on the overall probability of changing poverty status. 
Approaches which model the conditional probabilities of entry and exit have been extensively developed in the field of labour economics, typically to model transitions into and out of unemployment. They have also been used to model strike lengths, the intervals between purchases, biomedical histories, time to failure of electronic components, and other "event histories". Each of these models come under the general heading of "duration" or "hazard" models, since they model the probability of a spell having a certain duration or, equivalently, the probability of a spell ending given that it has not done so already ${ }^{4}$. To our knowledge these models have not been used to analyse poverty dynamics in developing countries before.

We wish to determine which household characteristics are important in increasing or decreasing the probability of entry or exit from poverty. Cox's proportional hazards model provides one of the most common methods to do this, by modelling the probability of entering/exiting poverty given a spell of the opposite state lasting up to the current period (Cox, 1972). The proportional hazards model also has the advantage of allowing the influence of various explanatory variables (known in this context as co-variates) on entry and exit probabilities to be assessed without having to specify the form of the underlying probability of exit or entry (known as the "baseline hazard"). This can be written as:

$$
\operatorname{Pr}_{i t}=\operatorname{Pr}_{0 t} \cdot e^{\beta . x_{i}}
$$

where

$\operatorname{Pr}_{\mathrm{it}}=$ the probability of household $\mathrm{i}$ exiting/entering poverty given that the spell has lasted until time $\mathrm{t}$

$\operatorname{Pr}_{0 \mathrm{t}}=$ the unknown baseline hazard

$\mathbf{B}=\quad$ a vector of coefficients

$\mathbf{x}_{\mathbf{i}}=\quad$ a vector of covariates for household $\mathrm{i}$

The covariates for each spell are fixed at the values which they hold when the household enters the spell. Thus we are investigating the way in which heterogeneity between the different households affects the probability of entry or exit by scaling the underlying baseline hazard $\operatorname{Pr}_{0 t}$. A positive coefficient increases the chances of the event occurring - a negative one reduces it. A household enters a spell on dropping below the income poverty line. The spell then continues until they rise above the income poverty line. Some households do not exit poverty by the end of the panel - in this case they are recorded as having a censored spell. However, censored spells are included in the calculation of the likelihood function. Since households can have more than one spell, estimates of the standard errors for the coefficients take account of clustering at the household level. In addition a robust method of calculating the variance-covariance matrix was used (the method used is the Huber-White or sandwich estimator (Lin and Wei, 1989)).

The results of the proportional hazards regression are then compared with the correlates of poverty resulting from poverty status regressions. Before presenting these results it is necessary to outline the data we are using and the precise method used to determine the poverty line.

$4 \quad$ Keifer (1988) and Allison (1982) provide good surveys of duration models. See Kalbfleisch and Prentice (1980) for a comprehensive exposition. 


\section{THE IFPRI PAKISTAN PANEL}

The data set used in this paper is taken from a panel data survey of around 800 households in 52 villages in rural Pakistan conducted by the International Food Policy Research Institute (IFPRI) between July 1986 and October 1991. Each household in the survey was interviewed a total of fourteen times between these dates, although due to the uneven spacing of visits it has only been possible to construct a panel for five annual rounds. Data collection took place in three provinces: Punjab, Sind and North-West Frontier Province (NWFP), and within each Province in one purposively sampled least developed district (Attock in Punjab, Badin in Sind and Dir in NWFP). In Punjab, a second more prosperous district, Faisalabad was also included in the panel as a control. Originally, the IFPRI team had also planned to include one least developed district (Kalat) from Pakistan's fourth province, Baluchistan, but survey work had to be suspended in this district after one year due to "special logistic conditions in that province" (Adams and He, 1995). So the final sample that we have available contains households from 52 villages in four districts and three provinces. It should be stressed that this sample cannot be regarded as representative of Pakistan, but, with the exception of Faisalabad, may be representative of poor rural areas within Pakistan.

The IFPRI survey collected information on households' composition and characteristics, their land ownership and use, crop production and distribution together with livestock and poultry ownership. Two specific concerns of the study were to document rural households' sources of income and details of their farm and non-farm expenditure (including weekly recall of food intakes), and detailed questions on these were administered to both men and women within the household. Unfortunately, the data collection procedures used to collect information on expenditure in rounds 13 and 14 are not strictly comparable to those in previous rounds, so that our attention in this paper is restricted to poverty measures based on income. Information on land, livestock and other asset ownership together with labour use of household members was also collected. A specialist module on education, migration and employment was administered in round 10 of the survey and a separate module on credit in round 13 of the survey.

We are able to "track" the incomes, assets and household characteristics of 686 households over all five years of the sample. Together with its geographical coverage this places the IFPRI panel in between the large-scale panels constructed from national sample surveys in China, Ethiopia and India with 3,000 or more households, and smaller micro-panels constructed for specific studies such as the ICRISAT panel in southern India, Muller's (1997) work in Rwanda, Kinsey et al. (1998) in Zimbabwe, and Scott and Litchfield (1994) in Chile. It is also important to recognise that unlike many data sets described as panels (including all the World Bank's Living Standard Measurement Surveys), the IFPRI panel allows for households to be tracked between more than two points in time. This opens up the possibility of an analysis of the impact of covariates on the probabilities of entry and exit into poverty - which is done later in this paper.

All previous studies using the IFPRI Pakistan panel have used a relative poverty line set equal to the bottom quintile of the distribution of either incomes or consumption expenditures, both expressed in per capita terms (Alderman and Garcia, 1993; Adams and He, 1995). Although this differs from the way in which the Pakistan Household Income and Expenditure Survey sets its poverty line, the adoption of a 
relative poverty line may be justified in two ways. ${ }^{5}$ First, there is no clear basket of goods to use within the sample districts/villages for constructing a poverty line using the cost of basic needs method. Second, when the alternative food energy intake method is used, the level of expenditure required for an individual to acquire Kcal 2,100 per day turns out to be remarkably similar to the bottom quintile of the per capita consumption distribution. Furthermore, as Alderman and Garcia argue, the consumption and income distributions of the panel are so well correlated that the cut-offs from their distributions may be used interchangeably.

Among the 686 households we are able to track through time, there is a remarkable increase in household size - from 8.7 members in $1986 / 87$ to 10.7 members in 1990/91. Further examination of the age distributions of households show that the majority of this increase comes from an increase in the numbers of infants and children per household. So if the poverty line is set equal to the bottom quintile of per capita income distribution, the poverty line will decline steadily over the sample. To avoid this problem, we have used a WHO equivalence scale to account for the fact that the majority of household size growth came from a larger number of children. ${ }^{6}$ Our poverty line was then set equal to the bottom quintile of the per adult equivalent income distribution in the first year of the panel - a figure of Rupees 2,000 per adult equivalent unit.

\section{RESULTS}

The first step in our analysis was to examine the correlates of poverty status using a standard poverty status regression. To do this, a logit model was estimated using data from the first year of the panel ${ }^{7}$. The dependent variable was one for poor households (real income per adult equivalent less than Rs 2,000 per year) and zero otherwise ${ }^{8}$. The results are shown in Table 1.

These results in Table 1 are in keeping with both intuition and what is already known about poverty in Pakistan. A household is more likely to be poor if it has a large number of members (household size) or a high dependency ratio. It is also more likely to be poor if it does not own any land although surprisingly this effect is not significant. Ownership of other assets, such as livestock and physical capital, reduces the probability of a household being poor. So too does the household head having completed primary school and the number of household members with secondary school education. The age of the household head (hh) reduces the probability of the household being poor marginally although this effect is not significant for most other years in the panel. The sex of the household head has no effect on poverty status. Finally residence in the district of Attock, the only non-irrigated area in the panel, is strongly associated with

$5 \quad$ Malik (1993) provides a useful survey of previous studies of poverty in Pakistan. The most common approach used to define a poverty line has been in terms of the consumption expenditure required to meet a minimum per capita calorie requirement - this is the approach used by Irfan and Amjad (1984), Ahmad and Allison (1990) and Ercelawn (1990). Typically a calorie requirement of Kcal 2,550 per day is used, as suggested by the Nutrition Cell of the Planning and Development Division of Pakistan, although lower figures such as Kcal 2,100 have also been used.

6 The equivalence scale used was taken from Dercon (1998) and is given in Appendix 1.

7 Similar results were obtained for the other four years.

8 The means and standard deviations for each of the variables are shown in Appendix 2. 
poverty status (relative to the excluded district of Badin) whilst living in Dir appears to reduce the risk of being poor.

Table 1: Logit Regression on Poverty

$\begin{array}{lrlr}\text { Number of observations }= & 686 & \text { Log Likelihood }= & -297.33 \\ \text { Proportion of correct Predictions }= & 0.81 & \chi^{2}(13)= & 94.11 \\ \text { Pseudo } R^{2}= & 0.1366 & \text { Prob }>\chi^{2}= & 0.000\end{array}$

$\begin{array}{lr}\text { Variable } & \text { Coefficient } \\ \text { Faisalabad } & 0.17 \\ \text { Attock } & 0.97 \\ \text { Dir } & -0.96 \\ \text { Household size } & 0.08 \\ \text { Age of hh head } & -0.02 \\ \text { Sex of hh head } & 0.41 \\ \text { Dependency Ratio } & 0.47 \\ \text { Basic education } & 0.05 \\ \text { Secondary education } & -0.37 \\ \text { Education of hh head } & -0.54 \\ \text { Do not own land } & 0.05 \\ \text { Value of livestock } & -0.03 \\ \text { Value of capital } & -0.01 \\ \text { Constant } & -0.82 \\ & \\ * \text { indicates significant at the } 10 \% \text { level; } * * \text { indicates significant at the } 5 \% \text { level } \\ \text { The Homer-Lemeshow goodness-of-fit test fails to reject the specification: } \\ \chi^{2}(8)=9.4 \text {; Prob }>\chi^{2}=0.31 \\ \text { See Appendix } 2 \text { for definitions of the variables. }\end{array}$

P Value
0.58
$0.00^{* *}$
$0.01^{* *}$
$0.03^{* *}$
$0.01^{* *}$
$0.74^{* *}$
$0.00^{* *}$
$0.33^{* *}$
$0.02^{* *}$
$0.03^{* *}$
$0.83^{* *}$
$0.00^{* *}$
$0.04^{* *}$
$0.10^{*}$

It is useful to compare these results with those obtained by Adams and He using the same data, but with regressors which were averaged over the three years of data then available (Adams and He, 1995). Adams and $\mathrm{He}$ also found that the value of livestock reduces the risk of poverty. They also found that the number of adult males and the number of males with middle or higher education significantly reduced the risk of poverty - in keeping with our results for the dependency ratio and the overall level of education. Adams and He found that ownership of irrigated land significantly reduced the chances of a household living in poverty - which is consistent with the sign of our (insignificant) land ownership dummy variable. Finally Adams and He found that living in Attock increased the chance of poverty and living in Dir reduced it. This is in agreement with our results for Attock and Dir.

Our results are also in keeping with generally accepted theory. Having a large household is generally correlated with poverty status, while a high dependency ratio decreases earning potential in relation to needs and therefore increases the risk of poverty (Lipton, 1983). Similarly, landlessness and lack of assets are likely to be associated with poverty. Note, however, that problems of endogeneity may arise here. Affluent 
households would be expected to have higher land and asset ownership than poor households. But since there is a large amount of transitory poverty, assets may be used to smooth consumption between good and bad years, and may therefore not necessarily be good indicators of poverty in any given year. Put differently, landlessness and lack of assets may be consequences rather than causes of poverty status.

It is important to ask how robust these results are to the choice of poverty line. Concerns about the lack of robustness of poverty comparisons have led to the widespread adoption of the techniques of "stochastic dominance" to ascertain the range of poverty lines over which results hold (Ravallion, 1992; Booth, 1997). Whilst the technique of stochastic dominance is not directly relevant here, the principle of establishing the sensitivity of the results to the choice of poverty line is. We therefore conducted the same logit regression for a range of poverty lines from Rs 1,500 to Rs 2,500 per adult equivalent. Table 2 summarises the variables which were found to be significantly different from zero for each of these poverty lines.

Table 2: Significance of Logit Variables for Different Choices of Poverty Line

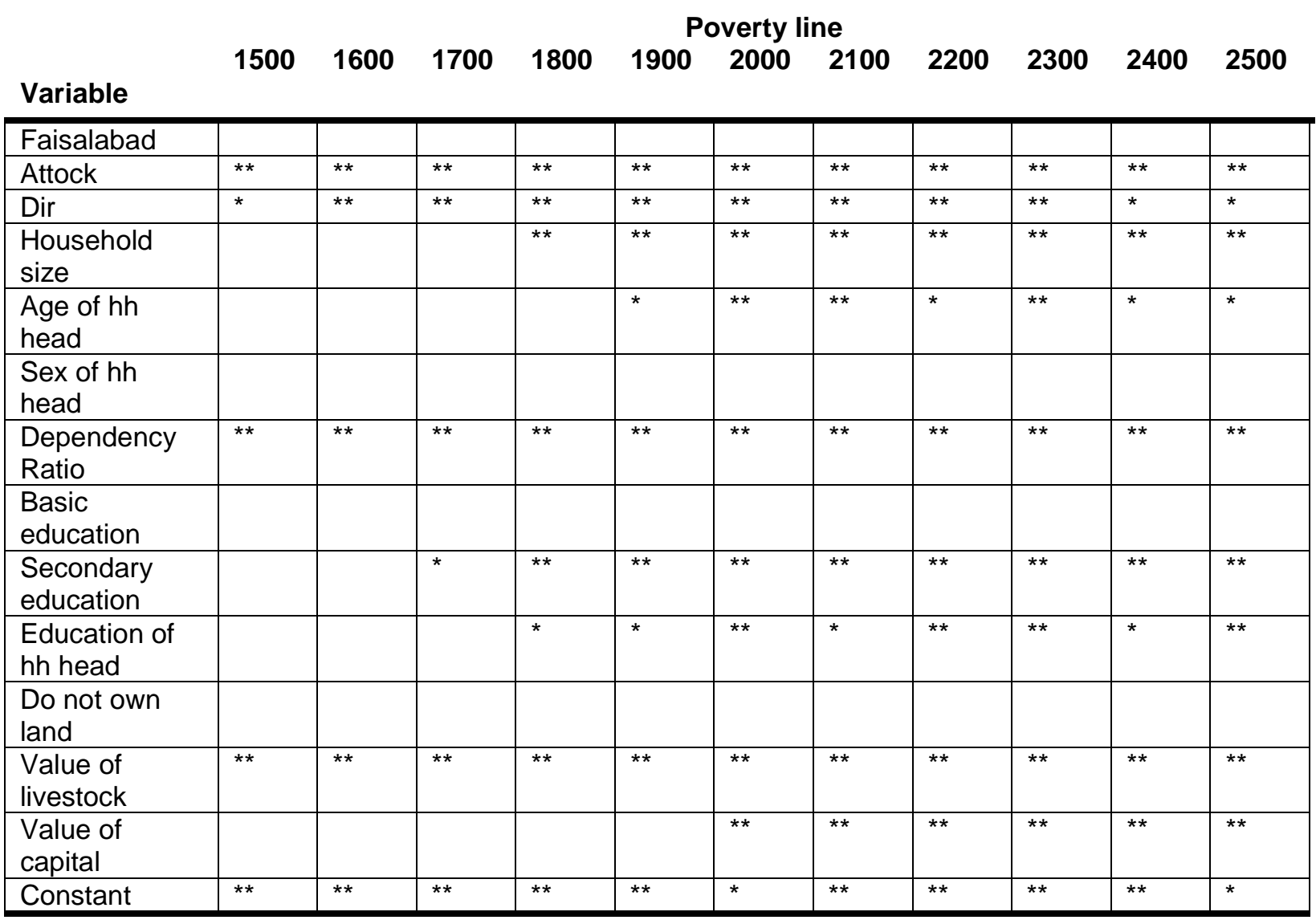

*indicates significant at the $10 \%$ level; **indicates significant at the $5 \%$ level

Overall, the Logit results seem quite robust to the choice of poverty line. The variables which are sensitive to the level of the poverty line are those representing education particularly of the household head, age of the household head, household size and the value of capital. The coefficients of these variables are not significantly different from zero at low poverty lines, but become so at higher poverty lines. The reasons for 
this are not entirely clear, but may be associated with the existence of threshold effects in the acquisition of large, and illiquid, capital assets.

The Logit regressions give a picture of the correlates of poverty status. However, as the methodology section makes clear, the incidence of poverty is determined by the probabilities of movements into and out of poverty. We therefore investigated the extent of poverty transitions in our data. Simple transition matrices between poverty and non-poverty were constructed for each sequential pair of years and between the first and last years of the panel. Again, the poverty line (Rs 2,000 per adult equivalent in 1986 constant Rupees as discussed above) represents the lowest quintile of the per adult equivalent income distribution in the first year of the panel and was held fixed for subsequent years. Thus although the boundary between poverty and non-poverty is determined relative to the income distribution in 1986/87, it remains absolute for the duration of the panel. The transition matrix for 1986/87 to 1987/88 is shown in Table 3 below.

Table 3: Poor/Non-Poor Transition Matrix 1986/87-1987/88

\begin{tabular}{|l|ll|l|}
\cline { 2 - 3 } \multicolumn{1}{l|}{} & \multicolumn{2}{c|}{$\mathbf{1 9 8 7 / 8 8}$} & \multicolumn{1}{|c|}{} \\
\hline $\mathbf{1 9 8 6 / 8 7}$ & Poor & Non-Poor & Total \\
\hline Poor & 67 & 71 & $138^{*}$ \\
Non-Poor & 80 & 468 & 548 \\
\hline Total & 147 & 539 & 686 \\
\hline
\end{tabular}

${ }^{*}$ Numbers of households with per adult equivalent income below the first 1986/87 quintile of Rs 2,000.

Table 3 indicates a poverty Head Count of 20.1 per cent in 1986/87, with 51.4 per cent of the poor escaping poverty and 14.6 per cent of the non-poor falling into poverty between these two years. Overall, more than a fifth of households moved between the two categories between these two years. This high level of mobility continues throughout the period of the panel.

Figure 3 shows the proportion of households entering and exiting poverty for each year. The figure shows that there are substantial movements into and out of poverty with between 20 per cent and 30 per cent of households exiting or entering poverty between any two years.

It is useful to express these movements in the forms of probabilities of becoming poor or non-poor. Thus between 1986/87 and 1987/88 the crude probability of becoming poor given that you were non-poor is 0.15 and the probability of escaping poverty given that you were poor is 0.51 . 


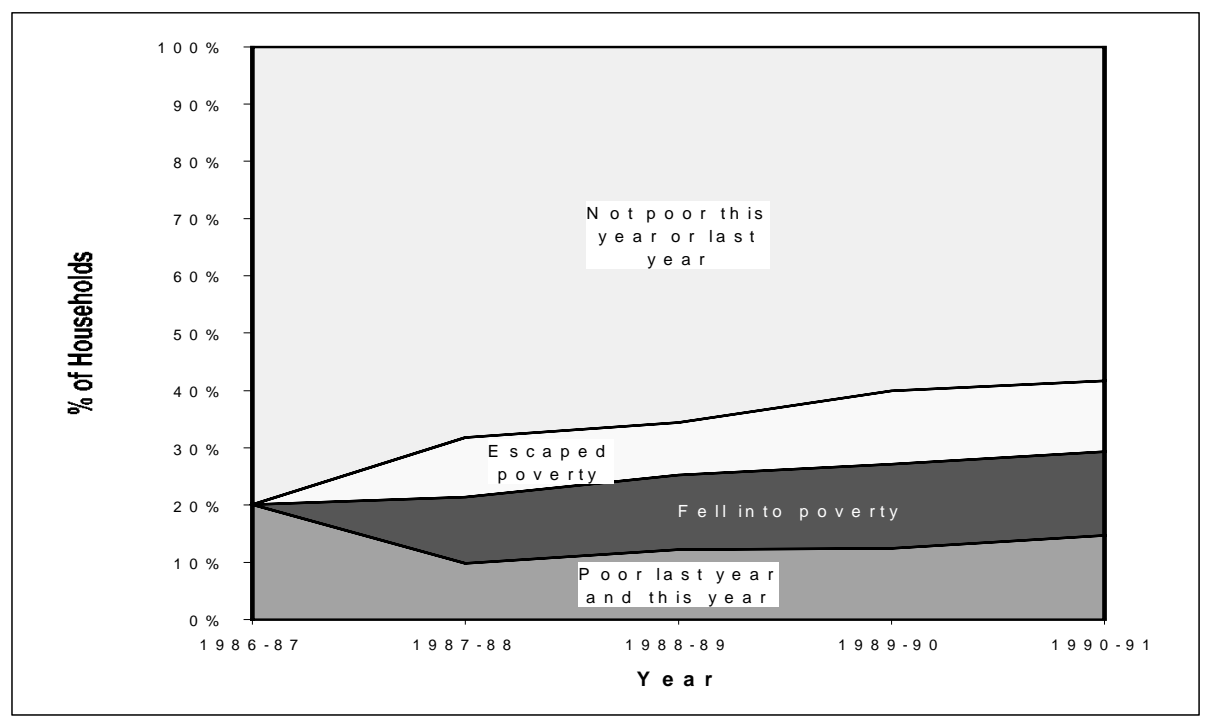

Table 4 shows the probabilities of entry and exit for each sequential pair of years and for the first-to-last year "transition" along with the headcounts and the total percentage of households moving between the two years.

Table 4: Simple Entry and Exit Probabilities

\begin{tabular}{|l|c|c|c|c|}
\hline \multicolumn{1}{|c|}{ Year } & $\begin{array}{c}\text { Probability of } \\
\text { Entering Poverty }\end{array}$ & $\begin{array}{c}\text { Probability of } \\
\text { Escaping } \\
\text { Poverty }\end{array}$ & $\begin{array}{c}\text { Head Count } \\
(\%)\end{array}$ & $\begin{array}{c}\text { Percentage of } \\
\text { Households moving }\end{array}$ \\
\hline $\begin{array}{l}1986 / 87- \\
1987 / 88\end{array}$ & 0.15 & 0.51 & 21.4 & 22.0 \\
\hline $\begin{array}{l}1987 / 88- \\
1988 / 89\end{array}$ & 0.17 & 0.43 & 25.2 & 22.2 \\
\hline $\begin{array}{l}1988 / 89- \\
1989 / 90\end{array}$ & 0.20 & 0.51 & 27.1 & 27.6 \\
\hline $\begin{array}{l}1989 / 90- \\
1990 / 91\end{array}$ & 0.20 & 0.46 & 29.3 & 27.0 \\
\hline \hline $\begin{array}{l}1986 / 87- \\
1990 / 91\end{array}$ & 0.24 & 0.49 & 29.3 & 29.0 \\
\hline
\end{tabular}

Note: Head Count is for the second year of the pair.

The earlier methodological discussion showed the relationship between the entry and exit probabilities and the steady-state poverty headcount using a simple Markov model (with the ratio of the entry to exit probabilities being equal to the ratio of the proportion of poor to the non-poor). We would not expect this relationship to hold exactly in any one year since the entry and exit probabilities change over time and therefore the headcount will never be at its steady-state value. However, it is notable that the headcount is similar to that which would be predicted by equation (2) using the entry and exit probabilities in Table 4. Furthermore the probability of entry into poverty increases over the years of the panel whilst the probability 
of escaping poverty does not decline. This increases the ratio of the entry to exit probabilities and so we would expect to see an increase in the poverty headcount which is precisely what is observed. ${ }^{9}$

The preceding analysis indicates that there are a large number of movements into and out of poverty each year. However, it does not show whether it is the same households or different ones which fall into or escape from poverty between years and therefore how often a typical household is in poverty during the five year period. Table 5 shows the number of years households experienced poverty during the five year period of the panel.

Note that these years are not necessarily consecutive - for example, a household experiencing three years of poverty during the five year period might experience them in the first, fourth and fifth years of the survey. Table 5 shows that almost 60 per cent of the households in the panel have some experience of poverty. However, a quarter are only in poverty for one year whilst over a third are in poverty for two or more years. Note, however, that only 3 per cent of the sample households had incomes below the poverty line in all five years of the panel.

Table 5: Number of Households Experiencing Different Periods of Poverty

\begin{tabular}{|l|l|l|}
\hline $\begin{array}{l}\text { Number of years in } \\
\text { poverty }\end{array}$ & $\begin{array}{l}\text { Number of } \\
\text { households }\end{array}$ & $\begin{array}{l}\text { Percentage of } \\
\text { households }\end{array}$ \\
\hline 0 (i.e. never poor) & 290 & $42 \%$ \\
\hline 1 & 163 & $24 \%$ \\
\hline 2 & 100 & $15 \%$ \\
\hline 3 & 68 & $10 \%$ \\
\hline 4 & 47 & $7 \%$ \\
\hline 5 (i.e. always poor) & 18 & $3 \%$ \\
\hline
\end{tabular}

Note: There are 686 households in the survey. Percentages do not add up to 100 per cent due to rounding.

The dynamic nature of poverty within the panel emphasises the importance of understanding the factors influencing entries into and exits from poverty. To calculate the impact of different explanatory variables on the chances of entering and exiting poverty we constructed a proportional-hazards model. The results of modelling the probability of entering poverty given a spell of non-poverty are shown in Table 6 . The results for the probability of exiting poverty given a spell of poverty are shown in Table 7.

9 Malik (1993) shows a reduction in poverty in rural Pakistan between 1984/85 and 1987/88 including in the agroclimatic regions which encompass the districts of the IFPRI survey. However, this is not necessarily inconsistent with rising poverty between $1986 / 87$ and $1987 / 88$ in the panel given that the latter was a bad year for both agricultural and industrial production. 
Table 6: Proportional Hazard Model of the Probability of Entering Poverty

$\begin{array}{lccc}\text { No. of subjects } & 279 & \text { Log likelihood }= & -529.3028 \\ \text { No. of entries } & 112 & \chi^{2}(13) & 29.90 \\ \text { Time at risk } & 347.85 & \text { Prob }>\chi^{2}= & 0.0049 \\ & & \\ \text { Variable } & \text { Coefficient } & \text { P Value } \\ \text { Faisalabad } & 0.30 & 0.302 \\ \text { Badin } & 0.21 & 0.39 \\ \text { Dir } & 0.32 & 0.155 \\ \text { Household size } & 0.07 & 0.003 \\ \text { Age of hh head } & -0.01 & 0.12 \\ \text { Sex of hh head } & -0.42 & 0.52 \\ \text { Dependency Ratio } & 0.20 & 0.011 \\ \text { Basic education } & -0.04 & 0.331 \\ \text { Secondary education } & -0.12 & 0.381 \\ \text { Education of hh head } & -0.18 & 0.38 \\ \text { Land owned } & -0.18 & 0.292 \\ \text { Value of livestock } & -0.02 & 0.01 \\ \text { Value of capital } & 0.00 & 0.478 \\ \text { * indicates significant at the 10\% level; ** indicates significant at the 5\% level } & \\ \text { Standard errors adjusted for clustering on household. } & \\ \text { See Appendix 2 for definitions of the variables. } & \end{array}$

The results show that the correlates of entries into and exits from poverty differ in important but unexpected ways from those of poverty status. In contrast to the Logit regressions, the district in which a household resides does not affect either its probability of entering poverty or its chances of exit. At the poverty line (Rs 2,000 per adult equivalent unit in 1986 prices) used for these regressions, education and asset variables also have very little impact on a household's chances of making a poverty transition. In marked contrast to the poverty status regressions, neither the ownership of land nor the value of physical capital affects the entry or exit probabilities. However, higher values of livestock owned both reduces the chances of falling into poverty and helps households to escape from poverty.

Nevertheless, the results of the proportional hazard model do serve to underline the importance of household composition, and more generally life-cycle effects, upon movements into and out of poverty. Larger households, particularly those with high dependency ratios, seem to be very vulnerable to falling into poverty and, if already poor, find it harder to escape. But although having a higher dependency ratio increases a household's chances of entering poverty, it does not significantly affect its chance of emerging from poverty at this poverty line. ${ }^{10}$

10 Similar asymmetries between upward and downward income movements have been observed for the British Household Panel Survey (Jarvis and Jenkins, 1998). 
Table 7: Proportional Hazard Model of the Probability of Exiting Poverty

\begin{tabular}{|c|c|c|c|}
\hline No. of subjects & 328 & Log likelihood = & $=-895.4$ \\
\hline No. of entries & 187 & $\chi^{2}(13)$ & 28.85 \\
\hline Time at risk & 364 & Prob $>\chi^{2}=$ & 0.0069 \\
\hline Variable & Coefficient & P Value & \\
\hline Faisalabad & 0.11 & 0.51 & \\
\hline Badin & -0.07 & 0.67 & \\
\hline Dir & 0.23 & 0.19 & \\
\hline Household size & -0.06 & $0.00 * *$ & \\
\hline Age of hh head & 0.00 & 0.26 & \\
\hline Sex of hh head & -0.37 & 0.66 & \\
\hline Dependency Ratio & 0.00 & 0.99 & \\
\hline Basic education & 0.01 & 0.84 & \\
\hline Secondary education & 0.07 & 0.23 & \\
\hline Education of hh head & 0.19 & 0.16 & \\
\hline Land owned & -0.04 & 0.73 & \\
\hline Value of livestock & 0.01 & $0.04^{* *}$ & \\
\hline Value of capital & 0.00 & 0.13 & \\
\hline
\end{tabular}

As with the Logit results, we re-estimated the proportional hazards model using different values of the poverty line to ascertain the robustness of our poverty transitions results. Table 8 shows which variables affected the probability of entry into poverty for poverty lines between Rs 1,500 and Rs 2,500 per adult equivalent at conventional levels of statistical significance. Table 9 shows the same information for exits. 
Table 8: Significance of Variables Explaining the Probability of Entering Poverty for Poverty Lines between Rs 1,500 and Rs 2,500 per Adult Equivalent

\begin{tabular}{|c|c|c|c|c|c|c|c|c|c|c|c|}
\hline Variable & 1500 & 1600 & 1700 & 1800 & ${ }_{1900}^{P}$ & $\begin{array}{l}\text { verty I } \\
2000\end{array}$ & 2100 & 2200 & 2300 & 2400 & 2500 \\
\hline Faisalabad & & & & & & & & & & & \\
\hline Attock & & & & & & & & & & & \\
\hline Dir & & & & & & & ** & * & * & ** & ** \\
\hline $\begin{array}{l}\text { Household } \\
\text { size }\end{array}$ & ** & ** & $\star *$ & $\star \star *$ & $\star \star$ & $\star *$ & $\star \star$ & $\star \star$ & ** & ** & $\star \star$ \\
\hline $\begin{array}{l}\text { Age of hh } \\
\text { head }\end{array}$ & & & & * & * & & & & & & \\
\hline $\begin{array}{l}\text { Sex of hh } \\
\text { head }\end{array}$ & $* *$ & ** & ** & ** & & & & & & & \\
\hline $\begin{array}{l}\text { Dependency } \\
\text { Ratio }\end{array}$ & & & & & & $* *$ & & & & ** & * \\
\hline $\begin{array}{l}\text { Basic } \\
\text { education }\end{array}$ & & & & & $\star *$ & & & & * & * & \\
\hline $\begin{array}{l}\text { Secondary } \\
\text { education }\end{array}$ & & & & & & & & & & & \\
\hline $\begin{array}{l}\text { Education of } \\
\text { hh head }\end{array}$ & & & & & & & & & & & \\
\hline $\begin{array}{l}\text { Do not own } \\
\text { land }\end{array}$ & & & & & & & & & & * & \\
\hline $\begin{array}{l}\text { Value of } \\
\text { livestock }\end{array}$ & ** & ** & ** & ** & ** & ** & & & & & \\
\hline $\begin{array}{l}\text { Value of } \\
\text { capital }\end{array}$ & ** & & & & & & & & * & & * \\
\hline
\end{tabular}

*indicates significant at the $10 \%$ level; **indicates significant at the $5 \%$ level

Table 9: Significance of Variables Explaining the Probability of Exiting Poverty for Poverty Lines between Rs 1,500 and Rs 2,500 per Adult Equivalent

\begin{tabular}{|c|c|c|c|c|c|c|c|c|c|c|c|}
\hline Variable & 1500 & 1600 & 1700 & 1800 & $1900^{P}$ & $\begin{array}{r}\text { verty } \\
2000\end{array}$ & $\begin{array}{l}\text { ne } \\
2100\end{array}$ & 2200 & 2300 & 2400 & 2500 \\
\hline Faisalabad & & & & & & & & & & & \\
\hline Attock & & & & & & & & & & & \\
\hline Dir & & & & & & & & & & & \\
\hline Household size & ** & $\star *$ & $\star \star$ & $\star *$ & $\star \star *$ & $\star *$ & $\star *$ & ** & ** & ** & $* *$ \\
\hline Age of hh head & * & & & * & * & & & & & & \\
\hline Sex of hh head & & & & & & & & & & & \\
\hline $\begin{array}{l}\text { Dependency } \\
\text { Ratio }\end{array}$ & & & & & & & & & & & \\
\hline Basic education & & & & & & & & & * & & \\
\hline $\begin{array}{l}\text { Secondary } \\
\text { education }\end{array}$ & & & & & & & & ** & ** & ** & \\
\hline $\begin{array}{l}\text { Education of hh } \\
\text { head }\end{array}$ & * & & & & & & * & * & ** & $\star \star$ & ** \\
\hline $\begin{array}{l}\text { Do not own } \\
\text { land }\end{array}$ & & & & & & & & & & & \\
\hline $\begin{array}{l}\text { Value of } \\
\text { livestock }\end{array}$ & * & & & & * & $\star \star \star$ & * & & $\star \star$ & * & * \\
\hline Value of capital & & & & & * & & & * & & & \\
\hline
\end{tabular}

*indicates significant at the $10 \%$ level; **indicates significant at the $5 \%$ level 
This sensitivity analysis for the proportional hazards model tells an interesting but complex story. The effect of household size on the probability of entry and exit is confirmed to be robust for a wide range of poverty lines but the impact of the dependency ratio is not. District of residence (relative to the excluded district of Badin) usually fails to influence entries and exits, although living in Dir appears to increase the probability of entering poverty for poverty lines above Rs 2,100. This is surprising given its irrigated status and poverty reducing effect in the Logit regression (and the similar finding by Adams and He (1995)).

For poverty lines below Rs 1,800 per adult equivalent unit belonging to a female headed household increases the chances of entering poverty. However, the very small number of female headed households in the panel suggests that this result should be treated with caution. Secondary education and education of the household head appear to have asymmetric effects - with education playing an important role in increasing the probability of exit but little role in reducing the chances of entry. This occurs primarily for higher poverty lines suggesting again that education may be subject to threshold effects.

The ownership of land does not significantly alter the chances of moving into or out of poverty confirming the result of the base case proportional hazards model. Similarly the value of capital owned has only sporadic effects. Livestock, on the other hand, continues to have consistent effects on both entry and exit probabilities. The value of livestock owned significantly reduces the chances of entry at low poverty lines and increases the chances of exit at higher poverty lines. This is consistent with Kurosaki's finding that livestock holdings enable households in the Pakistan Punjab to "smooth" their incomes by decreasing their exposure to risk both through ex ante income diversification and ex post decumulation of stocks (Kurosaki, 1998). However, examination of the size of the coefficients on livestock value, indicates that livestock's impact on entry and exit probabilities is extremely small.

\section{SUMMARY AND CONCLUSIONS}

In this paper we have investigated poverty dynamics in rural Pakistan using a unique five year panel data set from the second half of the 1980s. Our results confirm that while the incidence of income poverty in the panel is high, with between one-fifth and one-third of households in any year having incomes below the poverty line, turnover amongst the poor is also rapid. Around a half of poor households exit poverty from one year to the next but only 3 per cent of households had incomes below the poverty line in all five years of the panel. So while the poor are always with us, most remain in poverty only temporarily. Put differently, "the poverty problem" in Pakistan is not one of a stock of chronically poor people, but of a high turnover among the transitorily poor.

In order to understand what factors are driving the large number of transitions, we then compared the variables associated with poverty status and poverty transitions over a wide range of poverty lines. Conventional poverty status (Logit) regressions show that the probability of a household being in poverty is increased by its household size, the dependency ratio and district of residence but decreased by secondary education, land, the value of livestock and other assets owned. The age and sex of the household head together with basic education did not, however, alter a household's poverty status. 
We then moved on to investigate which household characteristics and geographic variables were associated with the probabilities of entering or exiting poverty using a partial likelihood proportional hazards model. Household size was found to increase the probability of entering poverty and decrease the probability of exiting poverty. This effect is consistent with the effect of this variable in standard poverty status regressions. However, neither the dependency ratio not district dummies, which were important in the poverty status regressions, have much impact on the probability of entries and exit from poverty. Furthermore, a number of other covariates (such as education, and livestock ownership) have asymmetric effects on movements into and out of poverty. Higher levels of education increase the probability that a household will exit poverty, but does not affect their entry probabilities. The value of livestock owned decreases the probability of entry into poverty for relatively low poverty lines, but does not affect the probability of exit until the poverty line is set much higher. Land and other asset variables affect neither entries into nor exits from poverty.

What policy implications can be drawn from this analysis? First, as has been observed in many other countries, a large proportion of the poor in rural Pakistan are only temporarily so. This suggests that if reducing long-term poverty is policymakers' prime concern then focusing anti-poverty interventions on the currently poor may involve a high degree of leakage. For even if it is possible to target the currently poor precisely, a large proportion of the population will move in and out of poverty between one year and the next. Second, if governments care primarily about reducing the poverty headcount they should focus their efforts on increasing exits from and decreasing entries into poverty. Since the correlates of poverty status and poverty transitions are not the same, it cannot be assumed that policy interventions that help the currently poor will also lead to a reduced incidence of poverty. Indeed because many of the correlates of current poverty status may be the consequences of poverty, focusing anti-poverty efforts on these correlates means that it is the symptoms rather than the causes of poverty that are being addressed.

It is, however, important to recognise that our analysis of the determinants of poverty transitions has, to date, only looked at the impact of static correlates on the probabilities of entry into and exits from poverty. A natural next stage in our analysis is to track key variables over time, in order to determine whether changes in them lead to poverty transitions. Alternatively, and as has been done in some industrialised countries, specific events (such as loss of employment, divorce or widowhood, or the birth of a child) might be identified which occur just before households move into or out of poverty. Although such event histories cannot definitively identify the causes of poverty, they will certainly be important in understanding the dynamic processes through which poverty occurs. 
APPENDIX 1: ADULT EQUIVALENCE SCALE

\begin{tabular}{|c|c|c|}
\hline Age & Male Weight & Female Weight \\
\hline 0 & & 0.33 \\
\hline 1 & 0.33 & 0.46 \\
\hline 2 & 0.46 & 0.54 \\
\hline $3-4$ & 0.54 & 0.62 \\
\hline $5-6$ & 0.62 & 0.70 \\
\hline $7-9$ & 0.74 & 0.72 \\
\hline $10-11$ & 0.84 & 0.78 \\
\hline $12-13$ & 0.88 & 0.84 \\
\hline $14-15$ & 0.96 & 0.86 \\
\hline $16-17$ & 1.06 & 0.86 \\
\hline $18-29$ & 1.14 & 0.80 \\
\hline $30-59$ & 1.04 & 0.82 \\
\hline $60+$ & 1.00 & 0.74 \\
\hline
\end{tabular}

The equivalence scale is based on a World Health Organisation equivalence scale quoted in Dercon (1998).

\section{APPENDIX 2: MEANS AND STANDARD DEVIATIONS OF THE VARIABLES}

\begin{tabular}{|l|c|c|}
\hline Variable & Mean & Standard Deviation \\
\hline Household size & 9.69 & 4.74 \\
\hline $\begin{array}{l}\text { Age of household } \\
\text { head }\end{array}$ & 46.9 & 14.0 \\
\hline $\begin{array}{l}\text { Sex of household } \\
\text { head (1 male; } \\
\text { female) }\end{array}$ & 1.006 & 0.078 \\
\hline Dependency ratio & 1.12 & 0.89 \\
\hline Basic education & 2.39 & 2.18 \\
\hline Secondary education & 0.61 & 1.09 \\
\hline $\begin{array}{l}\text { Education of } \\
\text { household head }\end{array}$ & 0.37 & 0.48 \\
\hline Do not own land & 0.38 & 0.48 \\
\hline $\begin{array}{l}\text { Value of livestock } \\
\text { (Rs 1,000s) }\end{array}$ & 17.4 & 61.1 \\
\hline $\begin{array}{l}\text { Value of capital (Rs } \\
1,000 s)\end{array}$ & 22.2 & \\
\hline
\end{tabular}

Dependency ratio is defined as the ratio of the number of household members under 16 years old to the number of members over 16 .

Basic education is the number of household members with primary and middle school education.

Secondary education is the number of household members with secondary or college education.

Education of household head is one if s/he has had some formal education and zero otherwise.

Do not own land is one if the household does not own land and zero otherwise.

Averages are across 686 households for all five years. 


\section{REFERENCES}

Adams, R. H., Jr., and J. J. He, 1995, 'Sources of Income Inequality and Poverty in Rural Pakistan',Research Report, 102, Washington DC: International Food Policy Research Institute.

Ahmad, E. and C. Allison, 1990, Poverty, Growth and Public Policy in Pakistan', Airlie, Virginia, USA: World Bank/International Food Policy Research Institute Research Conference.

Alderman, H. and M. Garcia, 1993, Poverty, Household Food Security, and Nutrition in Rural Pakistan', Research Report, 96, Washington DC: International Food Policy Research Institute.

Allison, P., D., 1982, Discrete-Time Methods for the Analysis of Event Histories', in Sociological Methodology, San Francisco: Jossey-Bass Publishers: 61-98.

Bane, M. J. and D. T. Ellwood, 1986, 'Slipping into and out of Poverty: the Dynamics of Spells', Journal of Human Resources, Vol 11 No 1: 1-23.

Booth, A., 1997, Rapid Economic Growth and Poverty Decline: A Comparison of Indonesia and Thailand 1981-1990', Journal of International Development, Vol 9 No 2: 169-187.

Cox, D. R., 1972, 'Regression Models and Life-tables (with discussion)', Journal of the Royal Statistical Society, Vol B 34: 187-220.

Dercon, S., 1998, 'Change in Poverty in Rural Ethiopia 1989-1995: Measurement, Robustness Tests and Decomposition', Mimeo, Oxford: Centre for the Study of African Economies.

Duncan, G. J., et al, 1993, 'Poverty Dynamics in Eight Countries', Journal of Population Economics, Vol 6: 215-234.

Ercelawn, A. A., 1990, 'Absolute Poverty in Pakistan: Poverty Lines, Incidence, Intensity', Karachi: University of Karachi, Applied Economics Research Centre.

Gaiha, R., 1989, 'Are the Chronically Poor Also the Poorest in Rural India?', Development and Change, Vol 20: 295-322.

Irfan, M. and R. Amjad, 1984, 'Poverty in Rural Pakistan', in Khan, A. R. and E. Lee (eds), Poverty in Rural Asia, Bangkok: International Labour Office/Asian Employment Program.

Jarvis, S. and S. P. Jenkins, 1998, 'How much Income Mobility is there in Britain', Economic Journal, Vol 108: $428-443$.

Kalbfleisch, J. D. and R. L. Prentice, 1980, The Statistical Analysis of Failure Time Data, Chichester: John Wiley and Sons.

Keifer, N. M., 1988, 'Economic Duration Data and Hazard Functions', Journal of Economic Literature, Vol XXVI, June: 646-679.

Kinsey, B., K. Burger, and J. Gunning, 1998, 'Coping with Drought in Zimbabwe: Survey Evidence on Responses of Rural Households to Risk', World Development, Vol 26: 89-110.

Kurosaki, T., 1998, Risk and Household Behaviour in Pakistan's Agriculture, Tokyo: Institute of Developing Economies/Kenkyusha Printing Company.

Lin, D. Y. and L. J. Wei, 1989, 'The Robust Inference for the Proportional Hazards Model', Journal of the American Statistical Association, Vol 84: 1074-1078. 
Lipton, M., 1983, Demography and Poverty',World Bank Staff Working Paper, 616, Washington DC: World Bank.

Malik, S. J., 1993, Poverty in Pakistan, 1984-85 to 1987-88', in Lipton, M. and J. Van der Gaag (eds), Including the Poor, Washington DC: World Bank Regional and Sectoral Studies, 487-519.

Mueller, C., 1997, Transient Seasonal and Chronic Poverty of Peasants: Evidence from Rwanda', Mimeo, Oxford: Centre for the Study of African Economies.

Ravallion, M., 1996, 'Issues in measuring and modeling poverty', Policy Research Working Paper, 1615, Washington DC: World Bank.

Ravallion, M., 1992, 'Poverty Comparisons: a Guide to Concepts and Measures',LSMS Working Paper, 88, Washington DC: World Bank.

Ravallion, M., and Jalan, J., 1996, Transient Poverty in Rural China', Policy Research Working Paper, 1616, Washington DC: World Bank.

Scott, C. D. and J. A. Litchfield, 1994, 'Inequality, Mobility and the Determinants of Income Among the Rural Poor in Chile, 1968-1986', Development Economics Research Programme, 53, London: STICERD, London School of Economics.

Walker, T. and J. Ryan, 1990, Village and Household Economies in India's Semi-Arid Tropics, Baltimore: John Hopkins. 